\title{
TRENDS IN THE DEVELOPMENT OF HYBRID DRIVES
}

\section{JOSEF MORKUS}

CTU in Prague, Faculty of Mechanical Engineering, Department of Automotive, Combustion Engine and Railway Engineering

E-mail: josef.morkus@fs.cvut.cz

\section{SHRNUTí}

Hybridizace pohonů motorových vozidel je jedním z hlavních trendů v posledních letech. Tento článek se zabývá růstem prodejů vozidel s hybridním pohonem a směry jejich technického vývoje, novým řešením převodových mechanismů, kapacitou a umístěním baterii a pokročilou formou rízení hybridního pohonu. Specifické trendy se týkají dobijení elektrických nebo hybridních autobusủ na autobusových zastávkách a ovlivnění vývoje soutěžních a závodních vozidel předpisy. Hybridní pohony také se objevuji v užitkových vozidlech, off-road aplikacích, člunech atd.

\section{KLÍČOVÁ SLOVA: HYBRIDNÍ POHONY, ELECTROMOTOR, BATERIE, PODPORA SPALOVACIIHO MOTORU, DOJEZD, SMĚ́R VÝVOJE}

\section{ABSTRACT}

The hybridization of motor vehicle drives is one of the major trends of recent years. This paper deals with the growth in sales of vehicles with hybrid propulsion, the directions of their technological development, new solutions for transmission systems, the capacity and location of the batteries and more sophisticated forms of hybrid drive control. Specific trends include the charging of electric or hybrid buses at bus stops and the regulation-influenced development of competitive and racing vehicles. Hybrid drives also appear in commercial vehicles, off-road applications, boats etc.

KEYWORDS: HYBRID DRIVES, ELECTRIC MOTOR, BATTERY, BOOST, RANGE, TREND OF THE DEVELOPMENT

\section{INTRODUCTION}

A combination of combustion engine and electric motor, i.e. a hybrid drive, is one of the ways of reducing the fuel consumption and emissions of motor vehicles. Their development has arisen largely due the pressure from emission regulations. Although the history of hybrids dates back to the late $19^{\text {th }}$ century, the first modern mass-produced hybrid vehicle, the Toyota Prius, was introduced as late as in1997 year. At present hybrid vehicles or hybridized models of current production vehicles are appearing in the production programs of most of the major vehicle manufacturers. Numerous variations of hybrid drives have been created, which today form a smooth transition between conventional cars with combustion engines, and battery-electric vehicles. Sales of hybrid car versions currently represent several percent of total car sales (excluding Japan, where it is over 20\%), but it has a strong upward trend. In the Czech Republic only 735 hybrids (excluding microhybrids) were sold in 2015 [1], but this is an increase of about $220 \%$ on hybrid sales in 2014. It is expected that after 2020, with an expected tightening of emission regulations, hybrid vehicles will constitute a substantial proportion of cars sold.

\section{HYBRID TYPES}

Technical development tends to plug-in hybrids, i.e. vehicles rechargeable from a mains socket, which allows a range on one battery charge of several tens of kilometers purely on electricity. This is sufficient for the normal daily mileage of most drivers. The overall range of plug-in hybrids is the same as conventional vehicles.

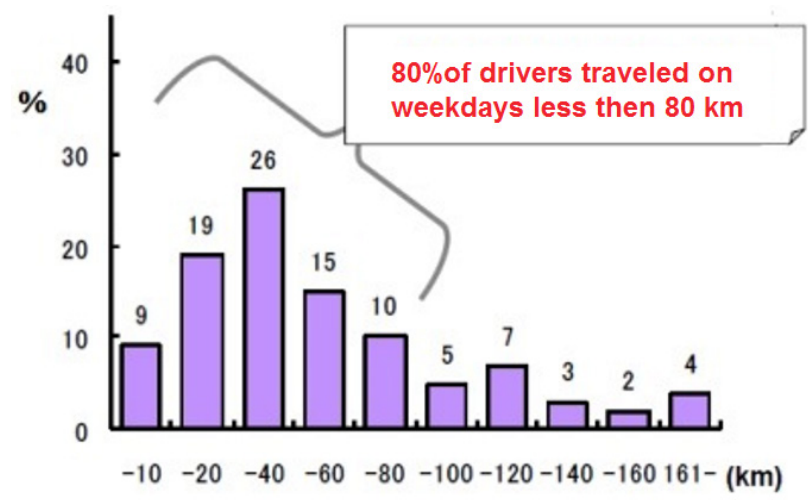

FIGURE 1: Daily mileage of vehicles in Germany [3] OBRÁZEK 1: Denní počet kilometrů vozidel v Německu [3] 
SALES OF HYBRIDS IN MILIONS CARS

$\begin{array}{llllllllllll}0,0 & 0,2 & 0,4 & 0,6 & 0,8 & 1,0 & 1,2 & 1,4 & 1,6 & 1,8 & 2,0 & 2,2\end{array}$

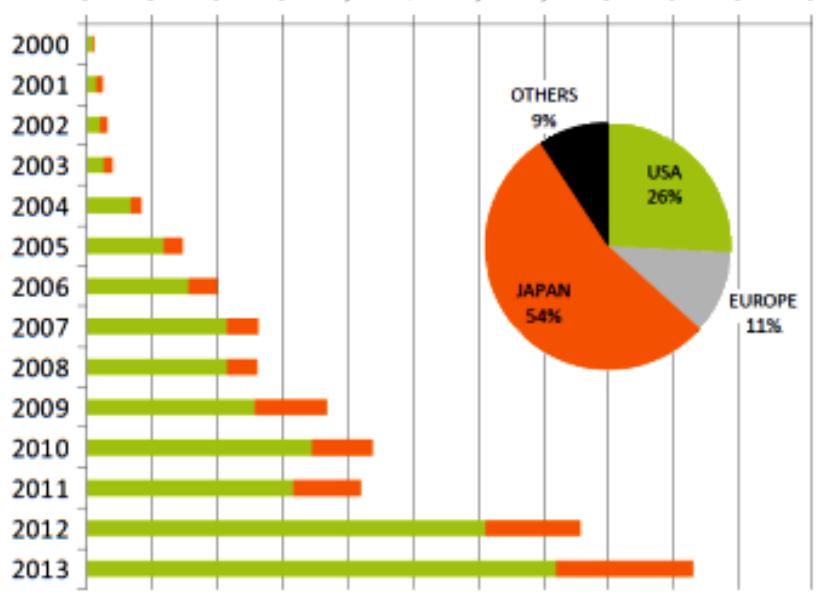

=TOYOTA $=$ OTHERS $=\%$ Micro hybrids not included

SHARE OF HYBRIDS ON TOTAL SALES OF PASSANGER CARS

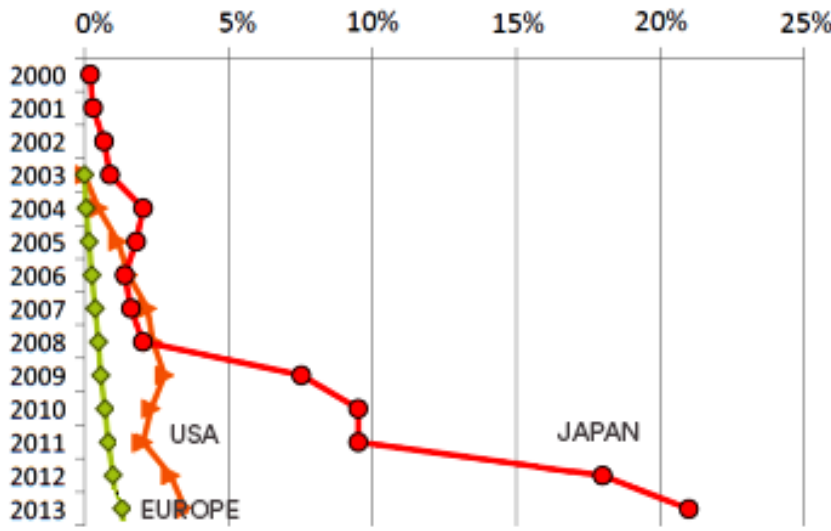

FIGURE 2: Sale of hybrid vehicles worldwide [2]

OBRÁZEK 2: Prodej hybridních vozidel na celém světě [2]
Because driving on electricity is significantly cheaper than driving on petrol or diesel, plug-in hybrids use bigger and therefore heavier and more expensive batteries, which increase the range on electricity, but also the price of the vehicle. Therefore, if they are not subsidized, simpler version hybrids with smaller and cheaper batteries will prevail in sales.

\section{BATTERIES}

The fundamental problem of all electric vehicles, i.e. hybrids and battery vehicles, is batteries. Despite the considerable funds invested into their development and undeniable progress, batteries are still heavy, large and expensive. One $\mathrm{kg}$ of petrol or diesel contains approx. 20 to 40 times more energy (with respect to transfer efficiency) than the same mass of an advanced lithium battery, and this proportion increases with the desired range [4]. The result is a small range for battery-vehicles, currently varying depending on many factors and driving style at around $150 \mathrm{~km}$. Another issue is where to place large batteries in the vehicle. The trend is to place them under the rear seats or into the floor for SUV cars so as not to restrict the usable space in the car.

\section{ELECTRIC MOTORS AND TRANSMISSIONS}

A noticeable trend is the integration of electric motors, most often synchronous permanent magnet motor, into the transmission system. In doing so, we can observe two basic directions: First, the electric motor becomes a part of the gearbox design and it is situated at the front of the step part of the gearbox. This leads to the possibility of the electric motor working in its optimal range and allows electric driving and electric braking (energy recovery) with disconnected combustion engine.

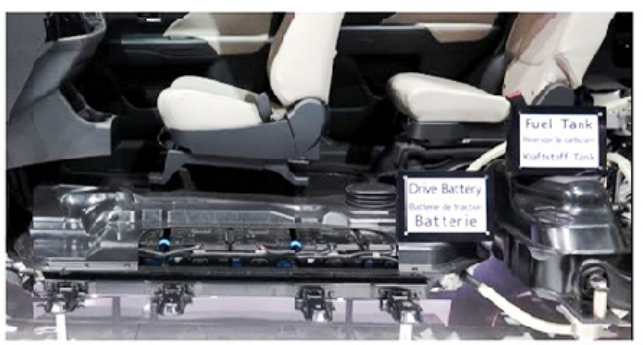

Mitsubishi Outlander Hybrid

FIGURE 3: Bulky and heavy batteries of full and plug-in hybrids were often placed under the car trunk instead of the spare wheel. Together with decreasing the volume of batteries, the trend is to place them under the rear seats (e.g. Toyota Yaris Hybrid) or in the central tunnel (e.g. Volvo XC 90 Hybrid). The popularity of SUVs leads to the possibility of placing the battery in a double floor (e.g. Mitsubishi Outlander).

OBRÁZEK 3: Objemné a těžké baterie full hybridů a plug-in hybridů byly často umístěny pod kufrem auta namísto rezervního kola. Spolu se snižením objemu baterií je trend umístit je pod zadními sedadly (např. Toyota Yaris Hybrid) nebo v centrálním tunelu (např Volvo XC 90 Hybrid). Popularita SUV vede $\mathrm{k}$ možnosti umístění baterie do dvojité podlahy (např. Mitsubishi Outlander). 


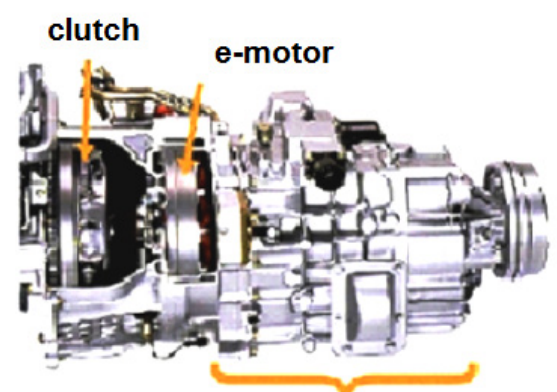

step part of the gearbox

FIGURE 4: Six speed automatic gearbox of a truck Mercedes-Benz Atego BlueTec Hybrid with built-in electric motor OBRÁZEK 4: Šesti stupňová automatická převodovka nákladního automobilu Mercedes-Benz Atego BlueTec Hybrid s vestavěným elektromotorem

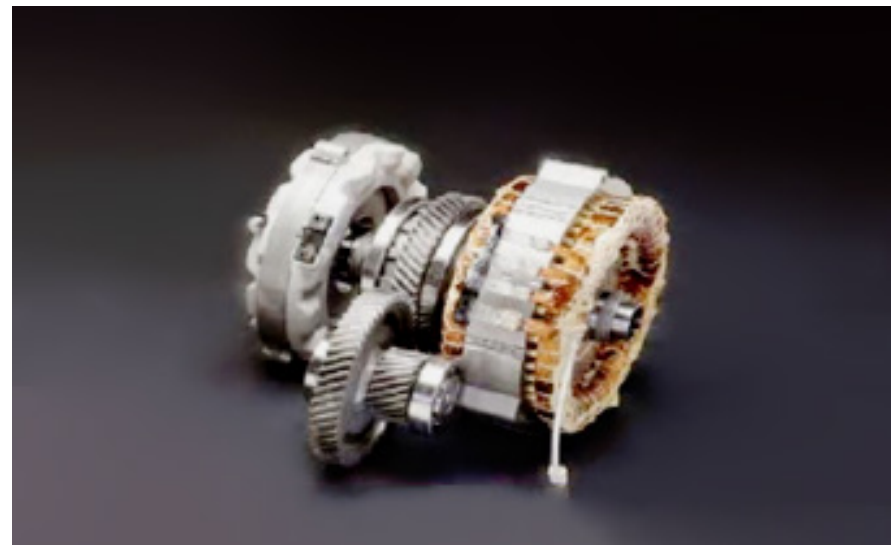

FIGURE 5: Toyota Hybrid Synergy Drive uses a planetary power divider, has no clutch or gear shifting members and continuously varies the gear ratio as a CVT

OBRÁZEK 5: Toyota Hybrid Synergy Drive využivá planetový dělič výkonu, nemá žádné spojky ani řadicí členy a plynule mění převodový poměr jako CVT

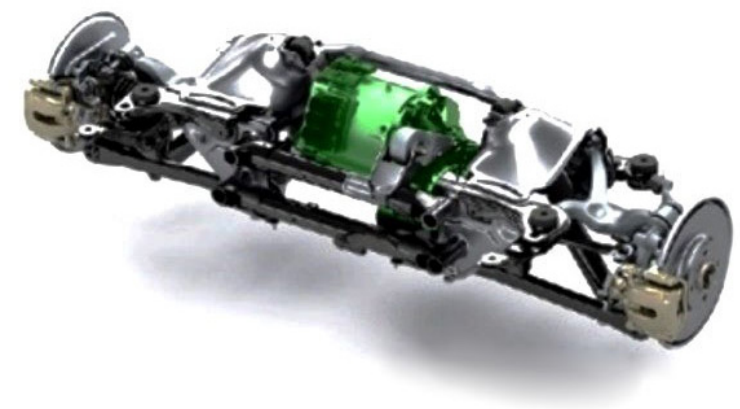

FIGURE 6: Hybrid4 models Peugeot / Citroen uses an electric motor connected to the rear axle via a gear and a clutch. Vehicles with this drive may drive in pure electric mode, hybrid mode or as a $4 \times 4$ OBRÁZEK 6: Modely Peugeot / Citroen HYbrid4 použivají elektrický motor prìpojený k zadní nápravě přes převod a spojku. Vozidla s tímto pohonem mohou jet v čistě elektrickém režimu, hybridním režimu nebo jako $4 \times 4$

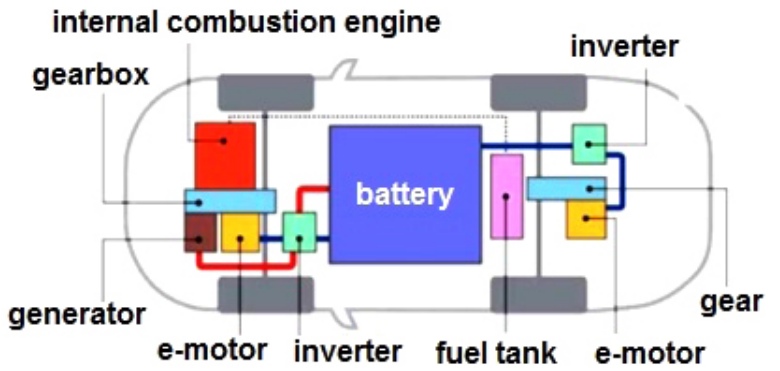

FIGURE 7: Mitsubishi Outlander has a battery built into the floor and electric motors at the front and rear axles. It can drive in pure electric mode on battery power or in so-called serial hybrid mode, where the electric power is supplied by a generator driven by ICE or in a parallel hybrid mode, in which ICE is mechanically connected to the axle and it is supported by electric motors.

OBRÁZEK 7: Mitsubishi Outlander má baterii zabudovanou do podlahy a elektromotory u přední a zadní nápravy. Může jet v čistě elektrickém režimu na energii $z$ baterií nebo $v$ tzv sériovém hybridního módu, kdy je elektrická energie dodávána generátorem poháněným spalovacím motorem nebo v paralelním hybridním módu, ve kterém je spalovací motor mechanicky spojen s nápravou a je podporován elektromotory.

The second direction fully replaces a step part of gearbox by an electric motor, uses its characteristics in a wider range and significantly simplifies the transmission. It often uses two electric machines and/or the possibility of switching between serial and parallel connection of the hybrid drive.

Another significant trend is the addition of an electric motor to the non-driven vehicle axle. Adding the electric motor to the rear axle of a conventional vehicle with front-wheel drive simultaneously creates a hybrid and $4 \times 4$ vehicle without a complicated transmission. In recent years a combination of hybrid drive unit on one axle and another electric motor on the second axle is more often used, which leads to improved dynamic properties and allows a higher degree of energy recovery during braking (e.g. Fig. 7).

A similar solution is popular with the sports and racing cars, where ICE (sometimes in combination with an electric motor) is usually positioned on the rear axle and another electric motor drives the front axle (e.g. Fig. 8).

\section{E-BOOST}

An alternatively method for using electrical energy to support the engine is the electric drive of a compressor. In this case the electric motor is not connected to the axle, but when support is requested, the motor via the compressor begins to supercharge the engine and thus enhances its power. A substantial advantage of this solution is that it can operate with a low voltage of 48 $\mathrm{V}$ and does not require an expensive high voltage battery. On the other hand, it cannot regenerate energy when braking. According to some authors, this solution is not regarded as "real" hybrid. 


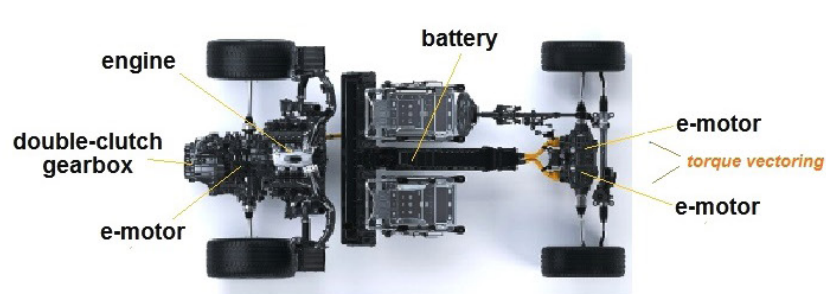

Honda NSX Acura

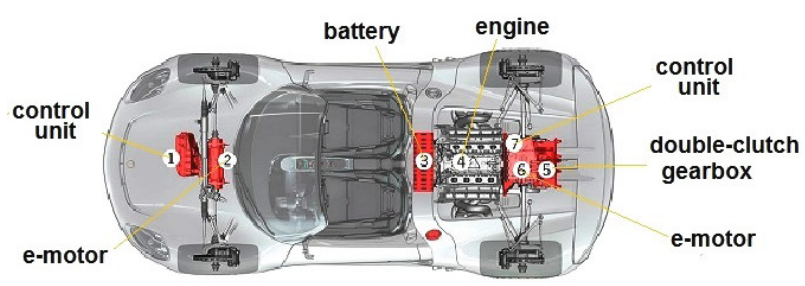

Porsche 918 Spyder

FIGURE 8: New Honda NSX Acura has three electric motors: one in $9^{\circ}$ dual-clutch transmission on the rear axle and two on the front axle. The battery is behind the seats and in the central tunnel. Porsche 918 Spyder has a V8 engine (4), which drives the rear axle through a dual clutch gearbox (5) with electric motor (6). A second electric motor (2) is on the front axle, the battery (3)behind seats, (1) and (7) are power electronics. OBRÁZEK 8: Nová Honda NSX Acura má tři elektrické motory: jeden v $9^{\circ}$ dvojspojkové převodovce u zadní nápravy a dva na přední nápravě. Baterie je za sedadly a v centrálním tunelu. Porsche 918 Spyder má motor V8 (4), který pohání zadní nápravu přes dvouspojkovou převodovku (5) s elektromotorem (6). Druhý elektromotor (2) je na přední nápravě, baterie (3) za sedadly, (1) a (7) je výkonová elektronika

Another version of this solution is connection of the electric motor to a turbocharger. In this case the electric motor can accelerate a turbocharger and thus shorten the engine response (turboeffect) to accelerator action. A turbocharger may also be braked by the electric motor to draw energy from the exhaust gases and to transform it into electric energy.

\section{COMPETITION AND RACING CARS}

In the highest categories of competition and racing vehicles a hybrid drive is directly required by regulations. Top vehicles for endurance races, such as the Le Mans 24 hour, have a combustion engine on the rear axle and electric motors on the front axle. In line with regulations introduced in 2014, F1 cars have not only turbocharged six-cylinder engines, but also two energy recovery systems: The first from kinetic energy during braking and the second from exhaust gases energy. Drive units are equipped with two electric motors: MGU-K connected to the crankshaft of the engine and MGU-H connected with the turbocharger.

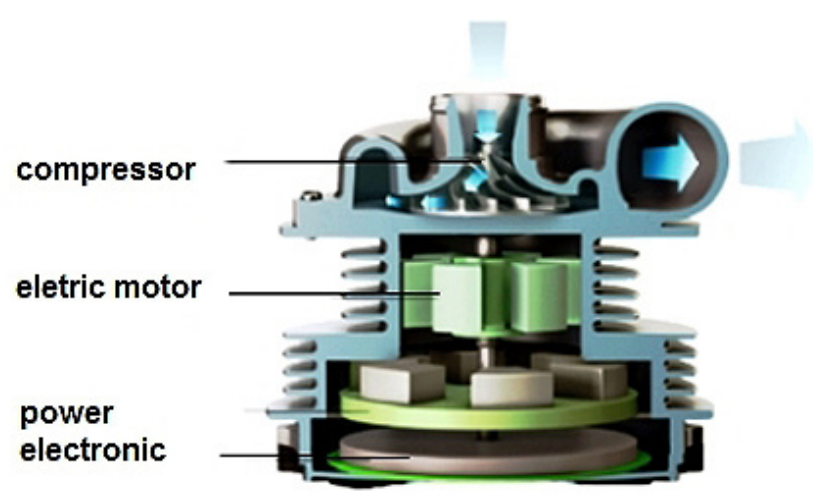

FIGURE 9: Electric compressor Valeo OBRÁZEK 9: Elektrický kompresor Valeo

In comparison with previous regulations the tenfold increase is permitted in the recovered energy per lap, which leads to significantly higher demands on energy management strategy during a lap.

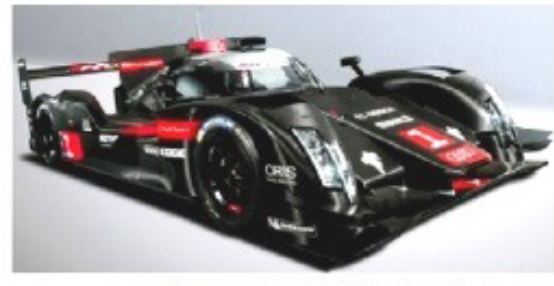

Audi R18 e-tron Quattro has Diesel V6 with electric turbocharger rear, two electric motors at front axle and flywheel in cabin

Toyota TS040 Hybrid has atmospheric V8 engıne and one electric motor rear, second electric motor at front axle and supercapacitor in cabin
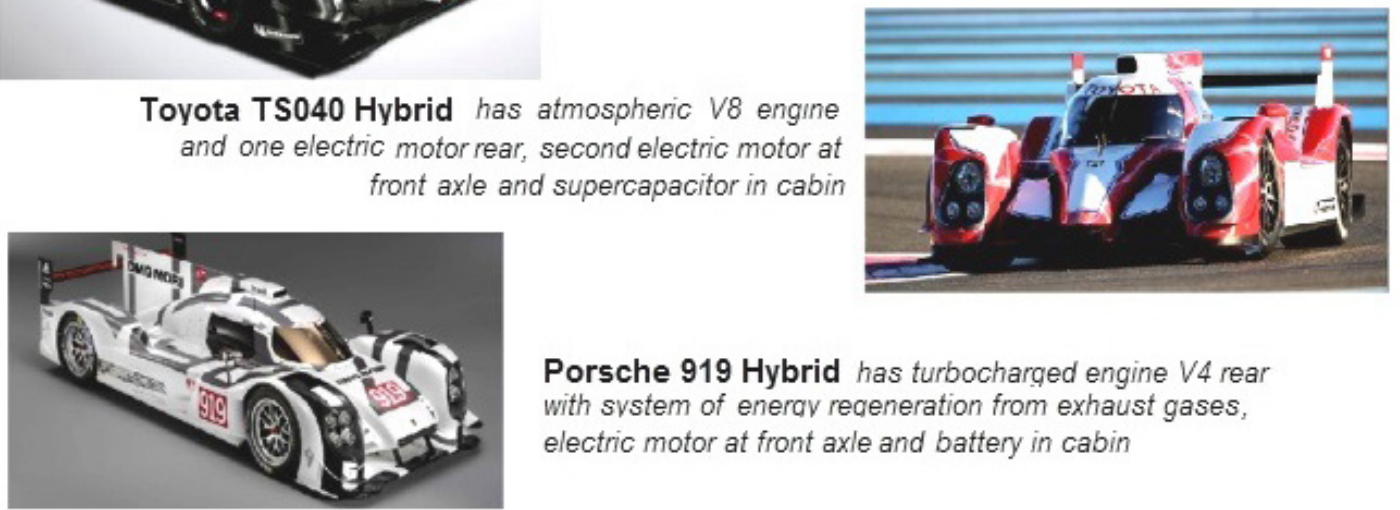

Porsche 919 Hybrid has turbocharged engine V4 rear with svstem of enerqv reqeneration from exhaust gases, electric motor at front axle and battery in cabin

FIGURE 10: Le Mans specials (2015)

OBRÁZEK 10:Speciály pro Le Mans (2015)

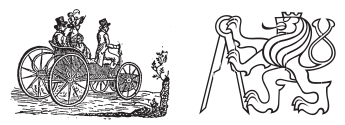




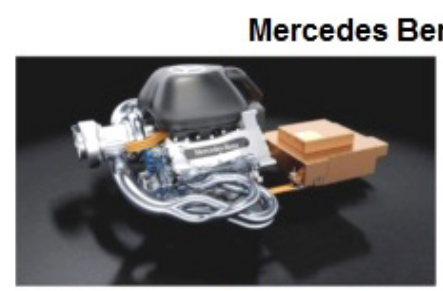

Power Unit

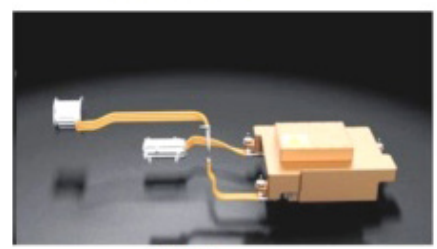

ERS

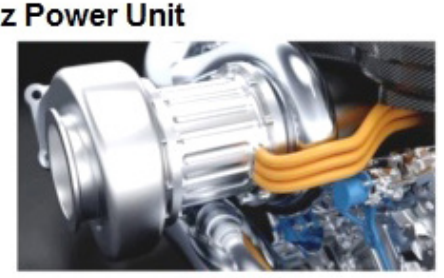

MGU-H

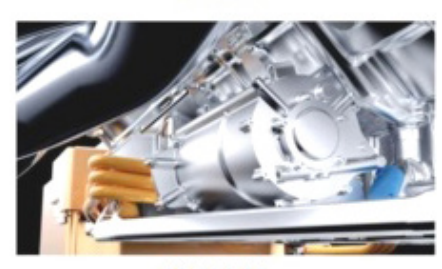

MGU-K

FIGURE 11: F1 energy recovery system

OBRÁZEK 11: F1 systém pro rekuperaci energie

\section{URBAN BUSES}

Another category of vehicles where hybrid drive often occurs is urban buses. Volvo already produces urban buses with only a hybrid version. A number of transport companies are trying to introduce electrobuses, but the basic problem is the discrepancy between bus range and its passenger capacity: When sufficient electric batteries are placed in the bus for the required daily range, there is a problem with exceeding axle load and it is necessary to limit the number of passengers. Chinese $12 \mathrm{~m}$ electrobus BYD

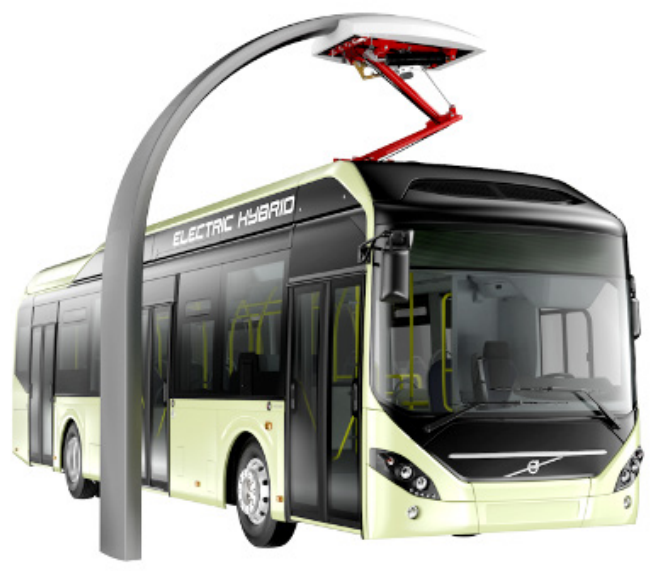

FIGURE 12: City bus Volvo 7900 Electric Hybrid is a combination of an electric bus with a hybrid bus. In the city it can run in pure electric mode and with the recharging of batteries at selected stops; outside the town center it runs in a hybrid mode, whereby the diesel engine is off at the stops, and bus leaves the stop on electric drive only. The diesel engine then starts at a speed of $20 \mathrm{~km} / \mathrm{h}$.

OBRÁZEK 12: Autobus Volvo 7900 Hybrid Electric je kombinací

elektrického autobusu s hybridním autobusem. Ve centru města může jet v čistě elektrickém režimu s dobíjením baterií na vybraných zastávkách; mimo centrum jede v hybridním režimu, přičemž vznětový motor je na zastávkách vypnutý a autobus odjiždí ze zastávky pouze na elektrický pohon. Vznětový motor se pak startuje při rychlosti $20 \mathrm{~km} / \mathrm{h}$.

has a battery range of up to $250 \mathrm{~km}$, but a capacity of only 54 passengers [5]. A solution is sought in charging batteries at bus stops. The problem, however, is expensive infrastructure with required charging currents up to $1000 \mathrm{~A}$. Therefore, many cities choose rather hybrids or a combination of both technologies.

\section{COMMERCIAL VEHICLES}

Implementation of hybrid drives into commercial vehicles began later, since around 2010, and the number of applications is steadily increasing. Hybrid drives are most often used in vehicles for goods distribution in cities. For this vehicles is typically used a parallel hybrid with electric motor between the engine and the gearbox; batteries are placed on the outer side of the vehicle frame.

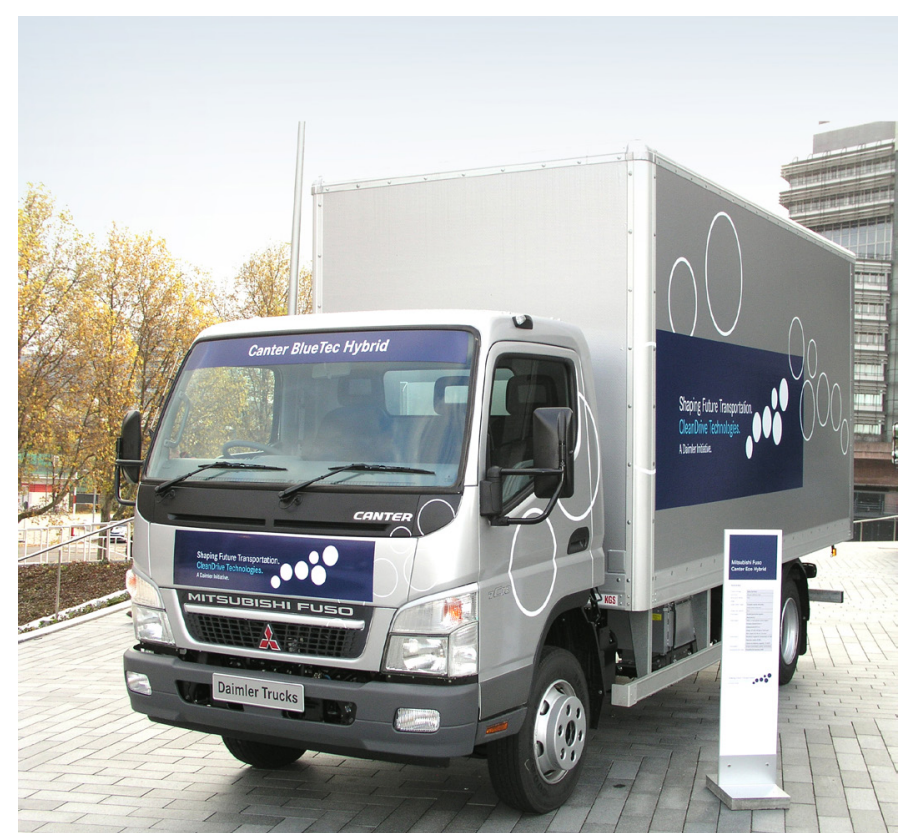

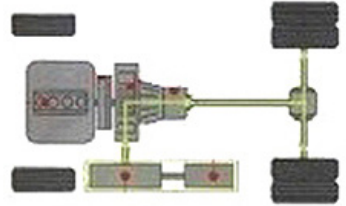

electric drive

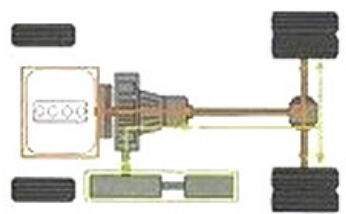

boost

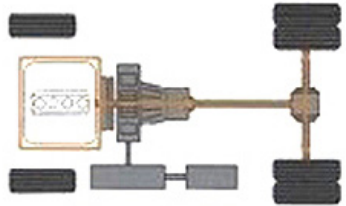

Diesel drive

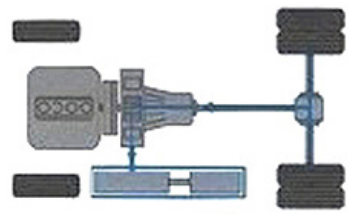

regeneration
FIGURE 13: Mitsubishi Fuso Hybrid is produced by a company which is a part of the Daimler-Benz Group. This car is manufactured in both Japan and Spain.

OBRÁZEK 13: Mitsubishi Fuso Hybrid vyrábí společnost, která je součástí Daimler-Benz Group. Tento vůz je vyráběn jak v Japonsku tak i ve Španělsku. 


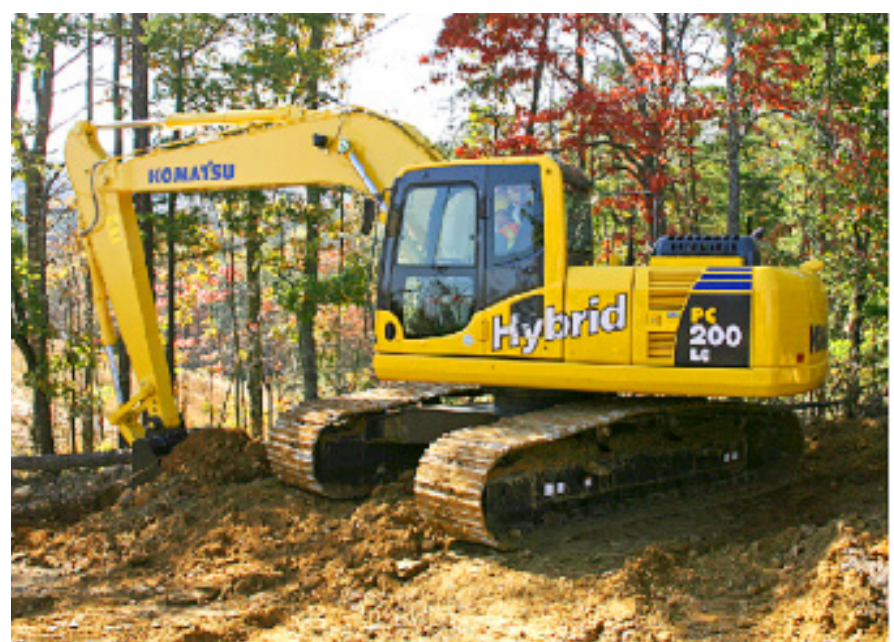

FIGURE 14: Excavator scoops up earth and turns the tower to the place where the earth is deposited. The drive of rotation is electrical, when rotation is braking the energy is stored in a super-capacitor and subsequently is used for rotation in the opposite direction. OBRÁzEK 14: Rýpadlo nabere zeminu a otáči věž na místo, kde zeminu vysype. Pohon otáčení je elektrický, při brzdění pohybu je energie uložena v superkondenzátoru a následně je použíta pro otáčení $v$ opačném směru.
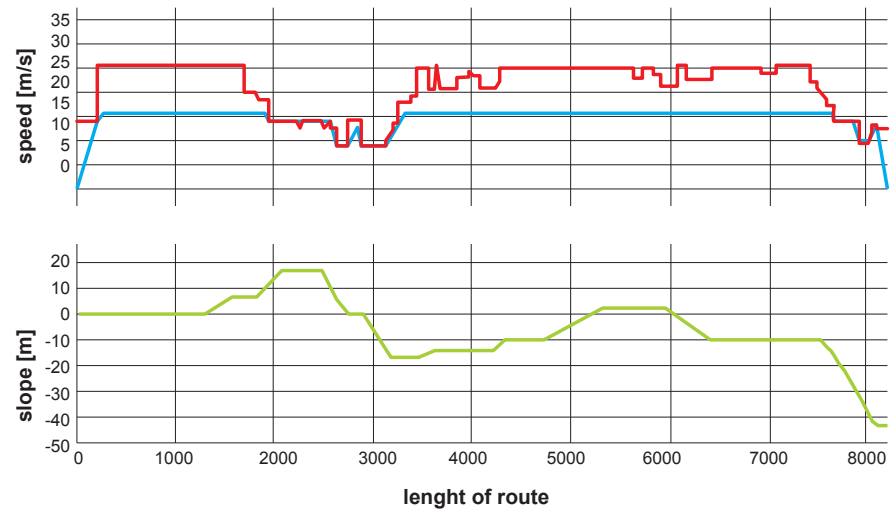

FIGURE 15: A sample of the optimum driving speed predictive calculation. The route is divided into sections; in each of them is a constant allowable speed (in red) and road slope (green). Blue is the course of optimal driving speed while minimizing energy consumption and with compliance with the required travel time [6].

OBRÁZEK 15: Př́klad prediktivního výpočtu optimální rychlosti jízdy. Trasa je rozdělena do sekcí; v každé z nich je konstantní povolená rychlost (červeně) a konstantní sklon silnice (zelená). Modrá je průběh optimální rychlosti jízdy s minimalizovanou spotřebou energie a s dodržením požadovaného času jízdy [6].

\section{OFF-ROAD APPLICATIONS}

A new trend is the use of hybrid drives for off-road applications, for example earthmoving machinery. These solutions may in some cases have significantly higher efficiency (lower fuel consumption) in comparison with the use of a hybrid drive for vehicles. An example is the use of electric propulsion for the rotation of an excavator upper part instead of the usual hydraulic actuator.

\section{HYBRID DRIVE CONTROL}

A special issue is control software for hybrid or purely electric drives. The purpose is to optimize the course of driving and power split between the combustion engine and the electric motor so as to obtain the lowest energy consumption and at the same time keep battery charge within required limits. Therefore, information from GPS and clouds is increasingly used for predictive and adaptive control. Electronics "see" further than the driver (the socalled electronic horizon). Actual driving control is then modified based on data from various sensors (radar, ultrasound, cameras) that monitors the immediate vicinity. However, detailed control procedures are the know-how of manufacturers and are generally not published.

\section{CONCLUSION}

It cannot be said there is a universal solution that could replace internal combustion engines. It can be expected that in the coming years and decades there will be greater diversification of different types of drives depending on the purpose of use of the vehicle, and hybrid drives will also have its role to play.

\section{ACKNOWLEDGEMENT}

This research has been realized using the support of EU Regional Development Fund in OP R\&D for Innovations (OP VaVpl) and using the support of EU FP 7 Project No. 608756, Integration and Management of Performance and Road Efficiency of Electric Vehicle Electronics. This support is gratefully acknowledged.

\section{REFERENCES}

[1] BUREŠ D., Český trh v roce 2015: Zájem o alternativní paliva roste. Jakým modelům se dařilo? Auto.cz 19. 1. 2016

[2] MORKUS J., Lectures "Hybridní pohony", FS ČVUT 2016. Data from EEVC congress, Brusel 2014

[3] Mitsubishi Motors: Elektrické vozy a jejich využití v rámci inteligentních sítí. Konference Japatech, Praha 2011

[4] MACEK J., General Problems of Hybrid Vehicle Design

[5] HINČICA L., Elektrobus BYD eBUS na zkouškách v DP Ostrava. Československý dopravák 3/2014

[6] STEINBAUER P., MACEK J., MORKUS J., DENK P. at al., "Dynamic Optimization of the E-Vehicle Route Profile," SAE Technical Paper 2016-01-0156, 2016, doi:10.4271/2016-01-0156 